\title{
Growth Hormone and Prolactin Producing Neoplastic Cells Present
}

National Cancer Institute

\section{Source}

National Cancer Institute. Growth Hormone and Prolactin Producing Neoplastic Cells

Present. NCI Thesaurus. Code C127196.

An immunohistochemical finding indicating the presence of growth hormone and prolactin producing cells in a tumor. 